\title{
Engineering of a borneol dehydrogenase from $P$. putida for the enzymatic resolution of camphor
}

\author{
Michael Hofer $^{1}$ (D) Julia Diener ${ }^{1} \cdot$ Benjamin Begander $^{2} \cdot$ Robert Kourist $^{3} \cdot$ Volker Sieber $^{1,2}$
}

Received: 27 November 2020 / Revised: 1 March 2021 / Accepted: 15 March 2021 / Published online: 12 April 2021

(C) The Author(s) 2021

\begin{abstract}
Several thousand different terpenoid structures are known so far, and many of them are interesting for applications as pharmaceuticals, flavors, fragrances, biofuels, insecticides, or fine chemical intermediates. One prominent example is camphor, which has been utilized since ancient times in medical applications. Especially (-)-camphor is gaining more and more interest for pharmaceutical applications. Hence, a commercial reliable source is needed. The natural sources for (-)-camphor are limited, and the oxidation of precious (-)-borneol would be too costly. Hence, synthesis of (-)-camphor from renewable alpha-pinene would be an inexpensive alternative. As the currently used route for the conversion of alpha-pinene to camphor produces a mixture of both enantiomers, preferably catalytic methods for the separation of this racemate are demanded to yield enantiopure camphor. Enzymatic kinetic resolution is a sustainable way to solve this challenge but requires suitable enzymes. In this study, the first borneol dehydrogenase from Pseudomonas sp. ATCC 17453, capable of catalyzing the stereoselective reduction of camphor, was examined. By using a targeted enzyme engineering approach, enantioselective enzyme variants were created with $E$-values $>100$. The best variant was used for the enzymatic kinetic resolution of camphor racemate, yielding $79 \%$ of (-)-camphor with an ee of $>99 \%$.
\end{abstract}

\section{Key points}

- Characterization of a novel borneol dehydrogenase (BDH) from P. putida.

- Development of enantioselective BDH variants for the reduction of camphor.

- Enzymatic kinetic resolution of camphor with borneol dehydrogenase.

Keywords Borneol dehydrogenase $\cdot$ Enzymatic resolution $\cdot$ Camphor $\cdot$ Racemate

\section{Introduction}

Terpenes are hydrocarbons classified by the number of isoprene units $\left(\mathrm{C}_{5} \mathrm{H}_{8}\right)$, ranging from hemiterpenes (one isoprene unit) to polyterpenes (more than eight isoprene units), and

Michael Hofer

Michael.hofer@igb.fraunhofer.de

1 Fraunhofer Institute for Interfacial Engineering and Biotechnology IGB, Schulgasse 11a, 94315 Straubing, Germany

2 Chair of Chemistry of Biogenic Resources, Campus Straubing for Biotechnology and Sustainability, Technical University of Munich, Schulgasse 16, 94315 Straubing, Germany

3 Institute of Molecular Biotechnology, Graz University of Technology, Petersgasse 14, 8010 Graz, Austria among natural compounds, they form one of the largest groups. Monoterpenes $\left(\mathrm{C}_{10} \mathrm{H}_{16}\right)$ are dimers of isoprene and occur in acyclic, monocyclic, bicyclic, and tricyclic forms. Monoterpenes are typically derivatized to containing oxygen or nitrogen atoms and are then referred to as monoterpenoids. Camphor is a bicyclic monoterpenoid containing oxygen. In nature, it is synthesized in plants (Banthorpe et al. 1972) and degraded by microorganisms such as $P$. putida (Bradshaw et al. 1959). Plants synthesize (+)- as well as (-)-camphor, but the most common and economically available enantiomer is $(+)$-camphor produced from the camphor tree, whereas (-)camphor is available by the oxidation of (-)-borneol but only at high costs. In addition, camphor as racemic mixture can be synthesized cost-efficiently from alpha-pinene, which is a side product from the pulp and paper industry (Zhen-dong and Liang-wu 2009). The demand for (-)-camphor for the synthesis of pharmaceuticals is constantly growing (Xu et al. 2005; 
Selescu et al. 2013; Sherkheli et al. 2013); therefore, a simple and efficient approach for the separation of camphor racemate is highly desirable. Enzymatic kinetic resolution of racemic mixtures is a common way to solve this challenge (Breuer et al. 2004; Verho and Backvall 2015). For example, alcohol dehydrogenases $(\mathrm{ADH})$ have been widely used for the oxidation of alcohols as well as for their reduction. Currently, no camphor-specific alcohol dehydrogenase is available; however, several borneol dehydrogenases (BDH) are known. Salvia officinalis harbors a (+)-borneol selective dehydrogenase, whereas Tanacetum vulgare harbors a (-)-borneol selective dehydrogenase (Dehal and Croteau 1987; Drienovská et al. 2020), whereas a non-selective alcohol dehydrogenase from Artemisia annua is described converting (+)- and (-)-borneol (Polichuk et al. 2010) as well as a (+)-borneol selective variant (Tian et al. 2015). Interestingly, the most active BDH enzymes to date are not from plant but have a bacterial origin and are the non-stereoselective borneol dehydrogenases from Pseudomonas sp. strain TCU-HL1 (Tsang et al. 2016). Besides BDH enzymes, only a tropinone reductase from Cochlearia officialis showed activity in oxidation of (-)-borneol as well as reduction of (+)-camphor (Reinhardt et al. 2014). However, none of these enzymes has shown activity or selectivity in the reduction of $(+/-)$-camphor that would suffice for the synthesis of optically pure (-)-camphor. In this study, the first borneol dehydrogenase capable of reducing camphor could be identified. Unfortunately, the wild-type enzyme has only a very low enantioselectivity. By modeling the enzyme structure, crucial residues for enantioselectivity were identified and used as targets for site-directed mutagenesis, resulting in several improved variants with an $E$-value $>100$ and with high remaining enzyme activity. The best enzyme variant was used for the catalytic separation of a camphor racemate (Fig. 1).

\section{Materials and methods}

\section{Materials}

Glucose dehydrogenase from Pseudomonas sp. was purchased from Sigma-Aldrich (UK).

\section{Bacterial strains and growth conditions}

E. coli $\mathrm{DH} 10 \mathrm{~B}$ was used as host for cloning procedures and E. coli $\mathrm{BL} 21(\mathrm{DE} 3)$ for protein production. The strains were grown in LB liquid media or on LB agar plates at $37^{\circ} \mathrm{C}$ for biomass production. Media were supplemented with 100 $\mu \mathrm{g} / \mathrm{ml}$ kanamycin. Borneol dehydrogenase production was induced upon addition of IPTG (final concentration $1 \mathrm{mM}$ ) at an $\mathrm{OD}_{600}$ of 0.6 , and cultivation was continued for $16 \mathrm{~h}$ at $16{ }^{\circ} \mathrm{C}$. Cells were collected by centrifugation $(4000 \times \mathrm{g}, 10$ min, $4{ }^{\circ} \mathrm{C}$ ). Pseudomonas sp. ATCC 17453 was used for cloning of the borneol dehydrogenase gene. Cells were grown on LB liquid media or LB agar plates at $30^{\circ} \mathrm{C}$.

\section{Cloning}

Pseudomonas sp. ATCC17453 was grown on LB agar containing $100 \mu \mathrm{g} / \mathrm{ml}$ ampicillin at $30^{\circ} \mathrm{C}$. A single clone was picked and transferred into $10 \mu \mathrm{l}$ aqua dest. and used as DNA template. The PCR conditions for amplification of the $b d h$ gene (GenBank: AB771747.1) were 5 min at $98{ }^{\circ} \mathrm{C}$ for DNA denaturing, followed by 25 cycles of denaturing at 98 ${ }^{\circ} \mathrm{C}$ for $10 \mathrm{~s}$, primer annealing at $61{ }^{\circ} \mathrm{C}$ for $20 \mathrm{~s}$, and strand extension at $72{ }^{\circ} \mathrm{C}$ for $30 \mathrm{~s}$. A last incubation step at $72{ }^{\circ} \mathrm{C}$ for 10 min finished the reaction using phusion DNA polymerase. The following pair of oligonucleotides was used for the reaction: 5-GATCCCATGGATGAAACCGCTAGCAGG-3 and 5-GATAGCGGCCGCTCAACCAGACAATCGATTG-3. For the creation of His-tagged variant, following primers were used: 5-TTGGTCTCGGATGCACCACCACCACC ACCACAAACCGCTAGCAGGTAAAAG-3 and 5GATAGCGGCCGCTCAACCAGACAATCGATTG-3. The PCR products were digested with $N c o$ I or BsaI and NotI and cloned into pET28a digested with the same restriction enzymes. All constructs were subsequently sequenced by Eurofins Genomics Germany GmbH.

\section{Enzyme modeling and substrate docking}

The three-dimensional structural models of Pseudomonas sp. ATCC 17453 borneol dehydrogenase were generated with the program SWISS-MODEL (Waterhouse et al. 2018), using the

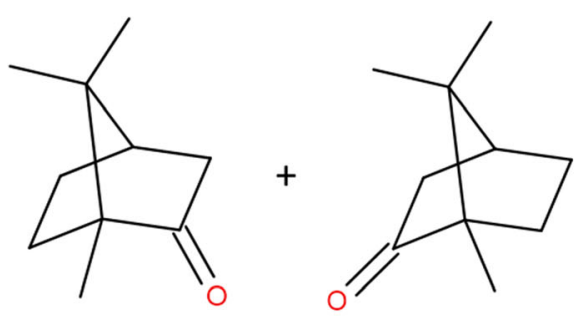

(1S)-(-)-Camphor

(1R)-(+)-Camphor

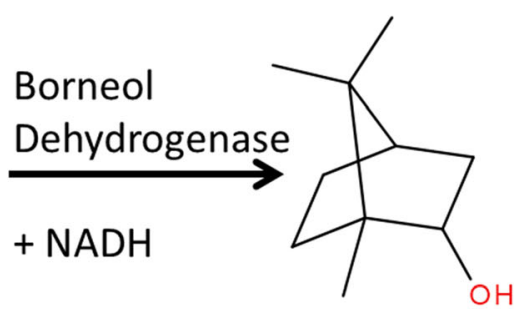

(+)-Borneol

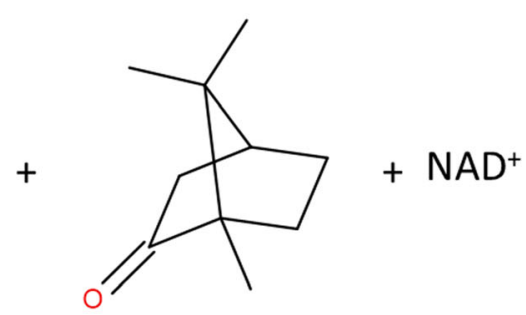

(1S)-(-)-Camphor

Fig. 1 Enzymatic kinetic resolution of camphor racemate using an enantioselective borneol dehydrogenase 
crystal structure of 3-alpha, 20 beta-hydroxysteroid dehydrogenases (PDB: 2HSD) as template (Ghosh et al. 1994). The protein and the substrate docking files were prepared using MGLtools (Morris et al. 2009). The substrate was docked into the models with AutoDock Vina (Trott and Olson 2010), based on the binding mode of $\mathrm{NAD}^{+}$in the template and the position of the catalytic residues in the models. The exhaustiveness was set to 8 , otherwise default parameters were used. The structure figures were prepared with the software program PyMOL v 2.4.

\section{Enzyme engineering}

The wild-type enzyme was engineered by site-directed mutagenesis at positions Q96, H98, E145, S146, N154, and Y188. The primers for mutagenesis were designed as described (Edelheit et al. 2009). PCR conditions were 2 min at $95{ }^{\circ} \mathrm{C}$ for DNA denaturing, followed by 16 cycles of denaturing at $95^{\circ} \mathrm{C}$ for $45 \mathrm{~s}$, primer annealing at $55^{\circ} \mathrm{C}$ for $30 \mathrm{~s}$, and strand extension at $72{ }^{\circ} \mathrm{C}$ for $12 \mathrm{~min}$. A last incubation step at $72{ }^{\circ} \mathrm{C}$ for 10 min finished the reaction using Pfu DNA polymerase (Promega GmbH, Germany). Afterwards, $1 \mu \mathrm{l}$ DpnI was added to the reaction mixture and incubated for $2 \mathrm{~h}$ at $37^{\circ} \mathrm{C}$, before ligation and transformation of E. coli $\mathrm{DH} 10 \mathrm{~B}$ were performed. All amino acids were mutated to amino acids of different properties or size creating seven focused libraries (Table 1). In the second mutation round, the best variants from round one were combined.

\section{Protein purification}

All purification steps were performed at $4{ }^{\circ} \mathrm{C}$. The cell pellet was resuspended in buffer A $(50 \mathrm{mM}$ potassium phosphate buffer $\mathrm{pH}$ 8.0, $20 \mathrm{mM}$ imidazole, and $0.5 \mathrm{M}$ sodium chloride). Then cells were disrupted in a French press at 1350 bar (TS 0.75 , Constant Systems, UK). After centrifugation for $30 \mathrm{~min}$ at $30.000 \times \mathrm{g}$, the soluble fraction containing BDH was passed through $0.2 \mu \mathrm{m}$ sterile filter, before loading on a $1 \mathrm{ml}$ HisTrap FF crude column (GE Life Sciences, USA). The column was previously equilibrated with buffer A. The column was washed with $50 \mathrm{mM}$ potassium phosphate buffer $\mathrm{pH} 7.5$, containing $50 \mathrm{mM}$ imidazole and $0.5 \mathrm{M}$ sodium chloride, and

Table 1 Selected amino acid changes for the site-directed mutagenesis

Q96: R, F, Y, W, K, E, N, L, M

H98: F, Y, W, Q, R, K, E, L, M, N

E145: M, L, N, I, S, H, K, R, Q, F, Y, W, G

S146: G, A, V, I, L, N, D, E, T

N154: L, I, M, E, S, H, K, W, Y, F, Q, R

Y188: W, H, R, Q, F, K, E, L, M, N
BDH was eluted with $50 \mathrm{mM}$ potassium phosphate buffer $\mathrm{pH} 7.5$, containing $300 \mathrm{mM}$ imidazole and $0.5 \mathrm{M}$ sodium chloride. The BDH fractions were pooled and desalted using a HiPrep 26/10 Desalting column (GE Life Sciences, USA) and $50 \mathrm{mM}$ potassium phosphate buffer $\mathrm{pH}$ 7.5. The protein stock could be stored for at least 1 week at $4{ }^{\circ} \mathrm{C}$ with only minor losses of activity. For the determination of optimum $\mathrm{pH}$ in regard to activity, the enzyme was desalted in $50 \mathrm{mM}$ potassium phosphate buffer ranging from $\mathrm{pH} 6.5$ to 9 or $50 \mathrm{mM}$ citrate-phosphate buffer ranging from $\mathrm{pH} 4$ to 6.5. Molecular absorption coefficient and molecular weight values of the proteins were determined via Expasy-Protparam (Gasteiger et al. 2005). Protein concentrations were calculated according to the Beer-Lambert law, after measuring the absorbance at $280 \mathrm{~nm}$.

\section{Enzyme analysis}

The oxidation reaction mixture contained $30 \mu \mathrm{g} / \mathrm{ml}$ enzyme, $50 \mathrm{mM}$ Tris- $\mathrm{HCl}$ at $\mathrm{pH} 7.5,1 \mathrm{mM} \mathrm{NAD}^{+}$and $1 \mathrm{mM}$ substrate at $30^{\circ} \mathrm{C}$. The reaction was started by the addition of enzyme. The reduction reaction mixture contained $500 \mu \mathrm{g} / \mathrm{ml}$ enzyme, $50 \mathrm{mM}$ citrate-phosphate buffer at pH 5.0, $1 \mathrm{mM} \mathrm{NADH}$, and $1 \mathrm{mM}$ substrate at $30^{\circ} \mathrm{C}$ for the enzyme analysis. The screening of engineered enzyme variants was done in $50 \mathrm{mM}$ Tris$\mathrm{HCl}$ at $\mathrm{pH} 7.5,1 \mathrm{mM} \mathrm{NADH}$ with $12.5 \mathrm{mM}$ formate, and 1 $\mathrm{mg} / \mathrm{ml}$ formate dehydrogenase. The reaction was started by the addition of $\mathrm{BDH}$ enzyme. For determination of $\mathrm{pH}$ optimum, the enzyme was desalted in the corresponding buffer and activity measured as described. The temperature optimum was determined by incubation of the assay solutions before and during the reaction at the corresponding temperature. Kinetic analysis was done at optimal $\mathrm{pH}$ and temperature values. The $K_{m}$ and $k_{\text {cat }}$ of $\mathrm{NAD}^{+}$were determined in the presence of $1 \mathrm{mM}$ substrate and 0.01, 0.02, 0.04, 0.08, 0.1, $0.2,0.4,0.6,0.8$, and $1 \mathrm{mM}$ cofactor. The $K_{m}$ and $k_{\text {cat }}$ for (+)borneol and (-)-borneol were determined in the presence of $1 \mathrm{mMNAD}^{+}$and $0.02,0.04,0.08,0.1,0.2,0.4,0.6,0.8,1$, and $2 \mathrm{mM}$ substrate. For data analysis, the enzyme kinetics module of SigmaPlot v13.0 was used.

\section{Calculation of enantioselectivity}

The enantiomeric ratio was calculated by Eq. (1). The conversion of the reaction was calculated according to Eq. (2).

$E=\ln \left(\left(e e_{p} *\left(1-e e_{s}\right)\right) /\left(e e_{p}+e e_{s}\right)\right) / \ln \left(\left(e e_{p} *\left(1+e e_{s}\right)\right) /\left(e e_{p} p+e e_{s}\right)\right)$

Conversion $=e e_{s} /\left(e e_{s}+e e_{p}\right)$

$e e_{s}$ and $e e_{p}$ are the $e e$ values of the remaining substrate and the formed product 


\section{Deracemization}

For the enzymatic kinetic resolution of camphor, $500 \mu \mathrm{g} / \mathrm{ml}$ of $\mathrm{BDH}$ was added to $50 \mathrm{mM}$ citrate-phosphate buffer at $\mathrm{pH} 5.0$, containing $0.05 \mathrm{mM}$ NADH, $12.5 \mathrm{mM}$ glucose, $17 \mathrm{U} / \mathrm{ml}$ glucose dehydrogenase, and $1 \mathrm{mM}$ camphor racemate. The mixture was incubated at $30{ }^{\circ} \mathrm{C}$ under shaking for $2 \mathrm{~h}$. Samples were taken after $0,15,30,45,60,75,90,105,120,135$, and $150 \mathrm{~min}$ and analyzed by GC as described.

\section{GC analysis}

Assay products were analyzed after product extraction from assays with equivalent amounts of ethyl acetate containing $1 \mathrm{mM}$ hexylbenzene as internal standard. GC analysis was performed with a Shimadzu GCMS model 2010 Q Plus connected to a MS detector (Single Quad). Chromatographic separation was achieved on a FS-HYDRODEX $\beta$-6TBD capillary column $(25 \mathrm{~m} \times 0.25 \mathrm{~mm}) ; 1.0 \mu \mathrm{l}$ of the sample was injected at $250{ }^{\circ} \mathrm{C}$ (Split-Splitless injector). The oven temperature was initially maintained at $60^{\circ} \mathrm{C}$ for $8 \mathrm{~min}$, then raised to $150{ }^{\circ} \mathrm{C}$ at $2.0^{\circ} \mathrm{C}$ per min, and then raised to $200{ }^{\circ} \mathrm{C}$ at $45^{\circ} \mathrm{C}$ per min and finally held for $2 \mathrm{~min}$. The column flow (carrier gas: helium) was $1.9 \mathrm{ml} / \mathrm{min}$. The products were identified by comparison of the retention times and mass spectra with authentic standards.

\section{Results}

\section{Cloning, protein expression, and purification}

Pseudomonas sp. ATCC17453 contains a borneol dehydrogenase on the CAM plasmid, which is part of the camphor degradation pathway (Bradshaw et al. 1959; Hartline and Gunsalus 1971). The cloned $b d h$ gene encodes a polypeptide chain of 260 amino acids with a predicted mass of $27.5 \mathrm{kDa}$ and a pI of 5.35. A NAD(H)-binding motif $\mathrm{G}_{13} \mathrm{XXXGXG}_{19}$ and a catalytic motif $\mathrm{Y}_{157} \mathrm{XXXK}_{161}$ with a $\mathrm{S}_{144}$ residue show that the enzyme belongs to the class of short-chain dehydrogenases (Kavanagh et al. 2008). In Pseudomonas sp. TCU-HL1, the $b d h$ gene has also a length of 260 amino acid residues and a similarity of $84 \%$ on protein-level with BDH from Pseudomonas sp. ATCC17453 (Tsang et al. 2016) (Fig. 2). After cloning into the expression vector pET28a with an N-terminal His-Tag, the protein could be expressed in $E$. coli in the soluble fraction and purified by nickel affinity chromatography, resulting in a single protein band with the expected size of $31 \mathrm{kDa}$ (data not shown).

\section{Protein characterization}

As shown in Fig. 3, BDH from Pseudomonas sp. ATCC17453 has its optimum at $\mathrm{pH} 7.5$ and an optimal reaction temperature of $30^{\circ} \mathrm{C}$ for the oxidation of borneol. The $\mathrm{pH}$ optimum for BDH from Pseudomonas sp. TCU-HL1 with an optimum at $\mathrm{pH} 8.5$ differs slightly. The analysis of the enzyme kinetic data revealed a Michaelis Menten behavior with apparent $K_{m}$ values for (+)-borneol of $0.095 \pm 0.004 \mathrm{mM}$ and $0.115 \pm 0.002 \mathrm{mM}$ for $(-)$-borneol and $0.06 \pm 0.005 \mathrm{mM}$ for NAD. The corresponding $k_{\text {cat }}$ values for (+)-borneol and (-)borneol were 0.89 and $0.97 \mathrm{~s}^{-1}$, respectively. This data is similar to the kinetic analysis of BDH from Pseudomonas sp. TCU-HL1 with $K_{m}$ values for (+)-borneol $0.2 \pm$ $0.01 \mathrm{mM}$ and $0.16 \pm 0.01 \mathrm{mM}$ for $(-)$-borneol and $k_{\text {cat }}$ values for (+)-borneol 0.75 and $0.53 \mathrm{~s}^{-1}$ (Tsang et al. 2016). BDH showed no preference for either one of the two borneol isomers $(E=1.7)$. Besides $(+)$ - and $(-)$-borneol, also $( \pm)$ isoborneol was accepted as substrate, whereas isopropanol, cyclopentanol, cyclohexanol, 1,2-butandiol, ( \pm )-2-butanol, L-carveol, and DL-menthol were not accepted.

\section{Reduction of camphor}

In contrast to all other described BDH enzymes so far (Polichuk et al. 2010; Sarker et al. 2012; Tian et al. 2015; Tsang et al. 2016; Drienovská et al. 2020; Khine et al. 2020), BDH from Pseudomonas sp. ATC17453 is able to catalyze the reduction of camphor to borneol with a maximal conversion rate at $30{ }^{\circ} \mathrm{C}$ and a $\mathrm{pH}$ optimum at 4.5 (Fig. 3). Since the protein was precipitating at $\mathrm{pH} 4.5$, all assays were performed at $\mathrm{pH}$ 5.0. A detailed kinetic analysis was not possible since substrate concentrations above the solubility level of camphor $(1.25 \mathrm{~g} / \mathrm{l})$ were necessary. The specific activity of the enzyme with (+)-camphor was $0.2 \mathrm{U} / \mathrm{mg}$ and with (-)camphor $0.18 \mathrm{U} / \mathrm{mg}$ at a substrate concentration of $1 \mathrm{mM}$.

\section{Molecular modeling, docking, and protein engineering}

The amino acid sequence of BDH from Pseudomonas sp. ATCC 17453 shows $28 \%$ identity and $37 \%$ sequence similarity to the previously crystallized short-chain dehydrogenase $3 \alpha, 20 \beta$-hydroxy-steroid dehydrogenase from Streptomyces hydrogenans (EC 1.1.1.53; Ghosh et al. 1994), which is the most similar crystallized enzyme so far. Therefore, $3 \alpha, 20 \beta$-hydroxy-steroid dehydrogenase was chosen as template to build the BDH homology model. In accordance with the sequence data, BDH prefers $\mathrm{NADH}$ as electron donor in the kinetic assay and was therefore used for modeling. The calculated model containing the cofactor as well as substrate provided a framework for the choice of amino acid residues for 
P. putida ATCC17453

P. putida TCU-HL1

P. putida ATCC17453

P. putida TCU-HL1

P. putida ATCC17453

P. putida TCU-HL1

P. putida ATCC17453

P. putida TCU-HL1

P. putida $\mathrm{ATCC} 17453$

P. putida TCU-HLI

MKPLAGKRIIVTGGAQGIGASVVRAYLAAGATVVSMDMIDKLGQQVVSEA

MKLLEGKRIIVTGGAQGIGASVVRAYIAAGATVASMDMNDTLGQQVVSEA

$\star \star x$

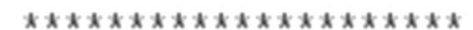

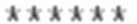

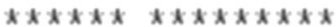

IEKHPDCSARYCHCDITDRTAVEKVFAAATWDMGGLDVMVNVAGVQRHSS

GKANPGCKSRYYHCNIADRPEVEKAFATAAEDMGGLDVMVNVAGVHRHSP

$x * x * x *$

$x * x * x$

$\star x * * x * x * x * x * x * * x *$

PDAISEDLFDLLFRVNVLGTMNTNGVAYSLMKSQGTGNI INFGSESGLTG

PDAIAEELYDML FRVNVLGT INTNAVAYRLMKGQGIGNI INFGSESGLTG

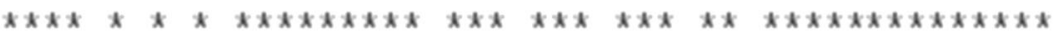

EIDNGLYAATKAAVHTWTRNVARQWGPDGIRINAVL PYMVT PMYVDFRNA

EINNALYSATKAAVHTWTRNVARQWGPDGIRINAVLPYMVTPMYVDFRNA

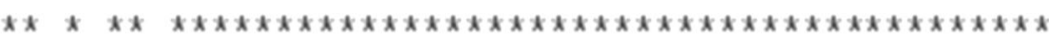

LSPEALASHDAATKADIPLGGKFGDVDKDLAPVMVFLASDASHFISRPDV

LSSEDLAAHDAATKTDIPLGGKFGDADKDLAPVMVFLASDASHFMT-----

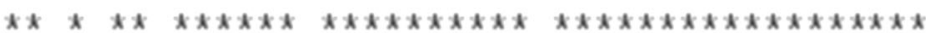

PGRRWAYCGAMSTAPPLRRQYVLFKGKANGNRLSG

-GQMFPVDGGLIAVR----------------------

$x \quad x$

Fig. 2 Sequence alignment of the cloned BDH gene from Pseudomonas sp. ATCC17453 with BDH from Pseudomonas sp. TCU-HL1 (Tsang et al. 2016) using ClustalW 1.7. Identical amino acids are marked with *. Active site amino acids are in bold

mutagenesis (Fig. 4). In the substrate binding pocket, the side chains of Q96, H98, E145, S146, N154, and Y188 are in close range to the substrate ( $5 \AA$ ) and not part of the active side. Accordingly, these residues were postulated to affect enzyme-substrate interaction, thus determining the substrate selectivity to yield (+)-camphor-specific variants. Therefore, these amino acids were selected for sitedirected mutagenesis. 

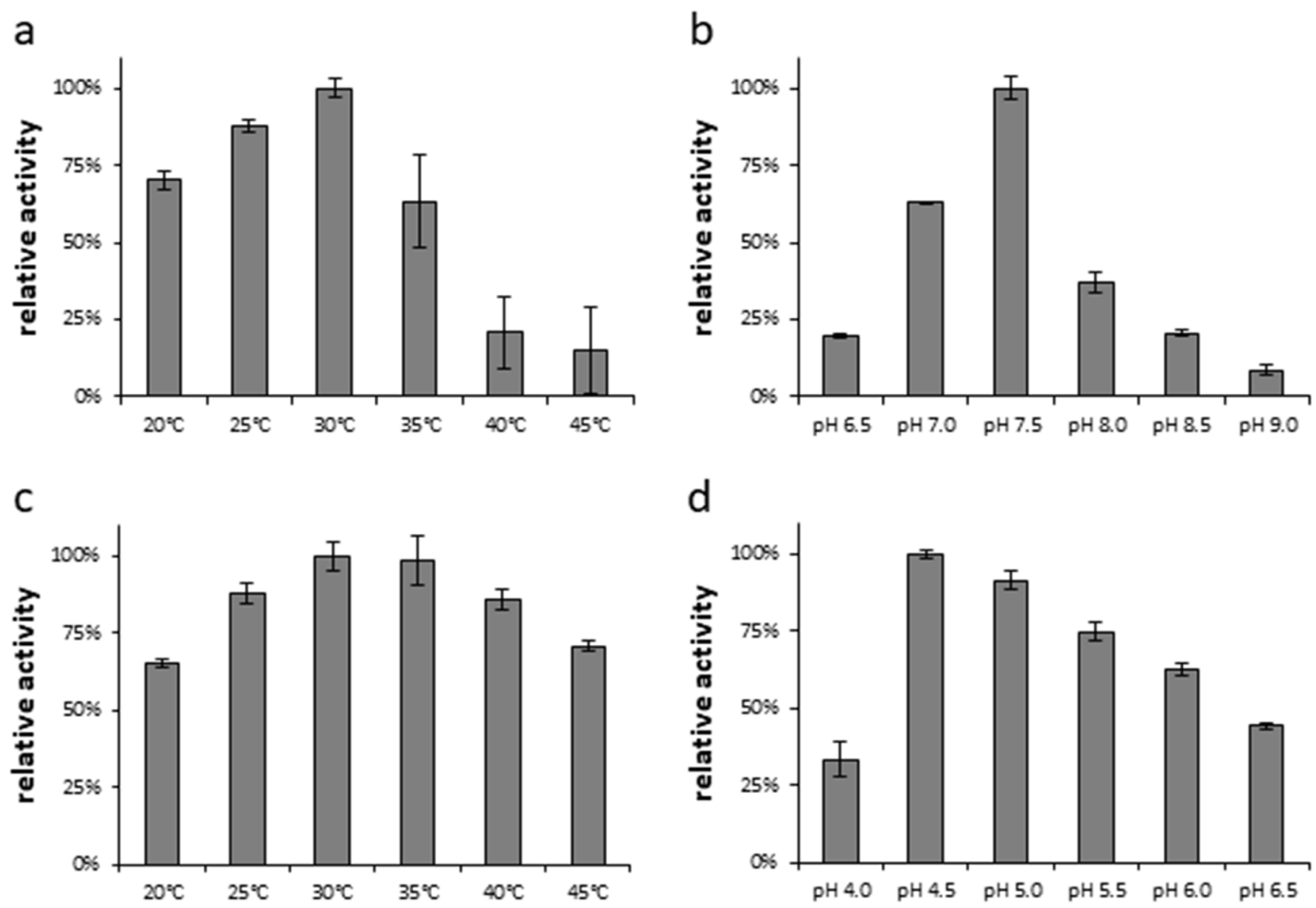

Fig. 3 Characterization of BDH from Pseudomonas sp. ATCC17453. $(\mathbf{a}+\mathbf{b})$ Temperature and $\mathrm{pH}$ optimum for the oxidation of $( \pm)$-borneol. $(\mathbf{c}+\mathbf{d})$ Temperature and $\mathrm{pH}$ optimum for the reduction of camphor

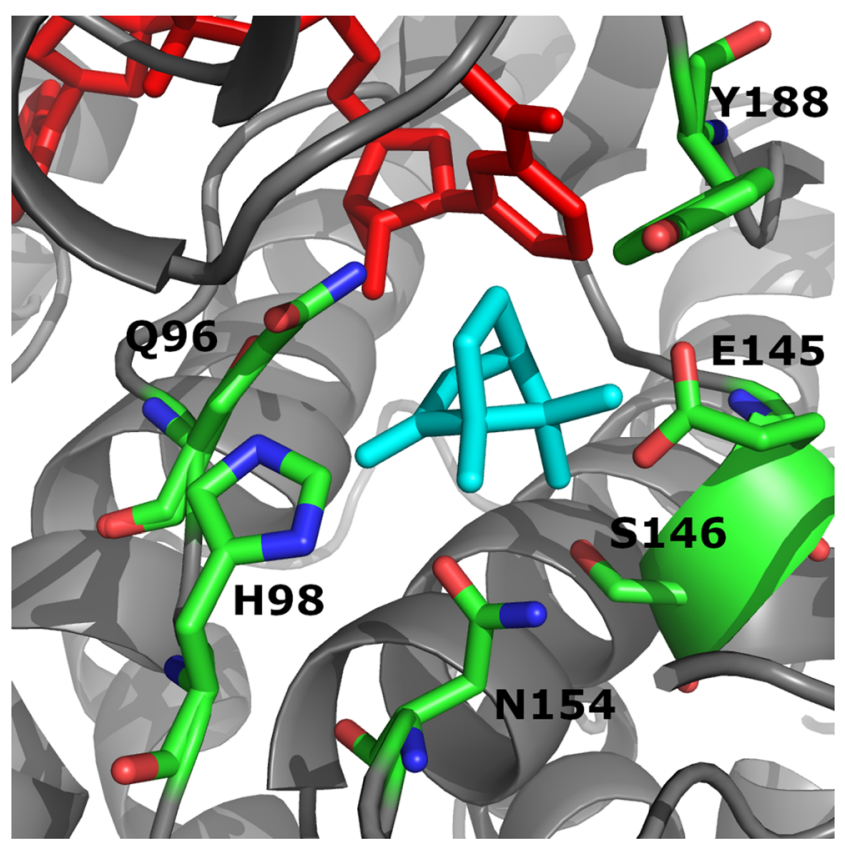

Fig. 4 Model of the substrate binding pocket of BDH from Pseudomonas sp. ATCC17453. NADH is shown in red, camphor is shown in cyan, and amino acids chosen for mutagenesis are shown in green

\section{Enzyme engineering for improved enantioselectivity}

BDH from Pseudomonas sp. ATCC17453 is not enantioselective for camphor (Table 2). Therefore, sitedirected mutagenesis was used to create focused libraries at six selected positions in the substrate binding pocket as described. None of the variants at position N154 showed any effect on the enzyme's enantioselectivity, whereas variants from libraries Q96, H98, and E145 only showed a minor improvement of camphor selectivity $(E(+)<4)$ (data not shown). Eleven variants from libraries E145, S146, and Y188 showed a significant increase in (+)-camphor selectivity $(E(+)>4)$ (Table 2). Nine of them had $E$-values ranging from 6 to 12.1. The best variants BDH_Y188T and BDH_Y188A showed synthetically useful $E$-values $(E>100)$. With the prospect to improve the conversion rate of $(+)$-camphor while retaining the high enantioselectivity, all variants of the first screening round with a conversion rate $>10 \%$ were combined with Y188T and Y188A, and the resulting double mutants were also screened. The combination of the mutations resulted in several highly enantioselective variants (Table 3 ). Although only the double mutants BDH_S146A/Y188T and 
Table 2 Kinetic resolution of racemic camphor catalyzed by improved mutants of borneol dehydrogenase from Pseudomonas sp. ATCC17453. The enantiomeric ratio E was calculated using Eq. (2)

\begin{tabular}{lllll}
\hline BDH variant & $e e_{s}$ & $e e_{p}$ & Conversion & $\mathrm{E}(+)$ \\
\hline Wild type & $24 \%$ & $9 \%$ & $27 \%$ & 1.7 \\
BDH_S146A & $8 \%$ & $71 \%$ & $11 \%$ & 6.3 \\
BDH_E145G & $6 \%$ & $71 \%$ & $8 \%$ & 6.3 \\
BDH_E145H & $4 \%$ & $71 \%$ & $5 \%$ & 6.0 \\
BDH_E145M & $27 \%$ & $68 \%$ & $29 \%$ & 6.9 \\
BDH_E145L & $30 \%$ & $67 \%$ & $31 \%$ & 6.6 \\
BDH_E145S & $59 \%$ & $59 \%$ & $50 \%$ & 7.0 \\
BDH_Y188L & $4 \%$ & $71 \%$ & $6 \%$ & 6.2 \\
BDH_Y188I & $9 \%$ & $74 \%$ & $11 \%$ & 7.3 \\
BDH_Y188V & $17 \%$ & $82 \%$ & $17 \%$ & 12.1 \\
BDH_Y188T & $28 \%$ & $98 \%$ & $22 \%$ & $>100$ \\
BDH_Y188A & $29 \%$ & $99 \%$ & $23 \%$ & $>100$ \\
\hline
\end{tabular}

BDH_S146A/Y188A resulted in higher conversion rates (40\% and 39\%) compared to the single mutants. The kinetic parameters of both mutants show an increased reaction velocity compared to the wild type for the oxidative reaction from (+)-borneol to camphor (Table 4).

\section{Enzymatic kinetic resolution of camphor}

For the targeted deracemization of camphor, BDH was coupled with glucose dehydrogenase (GDH) for cofactor recycling (Fig. 5), due to the inactivity of formate dehydrogenase under optimal BDH conditions. GDH catalyzes the oxidation of glucose to gluconolactone and reduces $\mathrm{NAD}^{+}$to $\mathrm{NADH}$, which is subsequently used by $\mathrm{BDH}$ for camphor racemate reduction to yield (+)-borneol and (-)-camphor. To investigate the suitability of GDH for the cascade, first, a steady-state analysis of the enzyme under the optimal reaction conditions for the recombinant $\mathrm{BDH}\left(30^{\circ} \mathrm{C}, \mathrm{pH}\right.$ 5.0) was

Table 3 Kinetic resolution of camphor catalyzed by improved double mutants of borneol dehydrogenase from Pseudomonas sp. ATCC17453

\begin{tabular}{lllll}
\hline BDH variant & $e e_{s}$ & $e e_{p}$ & Conversion & E (+) \\
\hline Wild type & $24 \%$ & $9 \%$ & $27 \%$ & 1.7 \\
BDH_E145M/Y188T & $11 \%$ & $97 \%$ & $10 \%$ & 72.6 \\
BDH_E145M/Y188A & $2 \%$ & $94 \%$ & $2 \%$ & 30.5 \\
BDH_E145L/Y188T & $19 \%$ & $100 \%$ & $16 \%$ & $>100$ \\
BDH_E145L/Y188A & $12 \%$ & $99 \%$ & $11 \%$ & $>100$ \\
BDH_E145S/Y188T & $5 \%$ & $96 \%$ & $5 \%$ & 50.0 \\
BDH_E145S/Y188A & $20 \%$ & $100 \%$ & $16 \%$ & $>100$ \\
BDH_S146A/Y188T & $65 \%$ & $97 \%$ & $40 \%$ & $>100$ \\
BDH_S146A/Y188A & $64 \%$ & $99 \%$ & $39 \%$ & $>100$ \\
\hline
\end{tabular}

Table 4 Kinetic analysis of wild type as well as enantioselective borneol dehydrogenase variants from Pseudomonas sp. ATCC17453

\begin{tabular}{lllll}
\hline BDH variant & $\begin{array}{l}K_{m}(-)- \\
\text { borneol } \\
{[\mathrm{mm}]}\end{array}$ & $\begin{array}{l}K_{m}(+)- \\
\text { borneol } \\
{[\mathrm{mm}]}\end{array}$ & $\begin{array}{l}k_{\text {cat }}(-)- \\
\text { borneol } \\
{\left[\mathrm{s}^{-1}\right]}\end{array}$ & $\begin{array}{l}k_{\text {cat }}(+)- \\
\text { boneol } \\
{\left[\mathrm{s}^{-1}\right]}\end{array}$ \\
\hline Wild type & 0.11 & 0.09 & 0.97 & 0.89 \\
BDH_S146A/Y188T & 0.73 & 0.46 & 0.13 & 3.32 \\
BDH_S146A/Y188A & 0.34 & 0.28 & 0.07 & 1.51 \\
\hline
\end{tabular}

done. The in silico analysis of the enzyme kinetics data revealed a Michaelis Menten behavior with apparent $K_{m}$ values for glucose $3.6 \mathrm{mM} \pm 0.35$ and $k_{\text {cat }} 1.3 \mathrm{~s}^{-1}$. Next, GDH and $\mathrm{BDH}$ were combined in a ratio that reflects similar activities under optimal reaction parameters to promote an optimal hydride flow. After $2.5 \mathrm{~h},>99 \%$ of (+)-camphor was converted to (+)-borneol with an $e e_{P}$ of $75.1 \%$, while the process yielded $79 \%$ of the target compound (-)-camphor with an $e e_{S}$ of $>$ 99\% (Fig. 6). Reducing the incubation time increases the yield of (-)-camphor but at the expense of reduced $e e_{S}$.

\section{Discussion}

BDH from Pseudomonas sp. TCU-HL1 and the BDH from Pseudomonas sp. ATCC 17453 have a similarity of $84 \%$ with only 41 differing amino acids. Point mutations are well known for influencing protein solubility (Smialowski et al. 2007; Tian et al. 2010; Klesmith et al. 2017), which might be the reason for the good solubility of BDH from Pseudomonas sp. ATCC17453 in contrast to the low solubility of BDH from Pseudomonas sp. TCU-HL1. The activity of BDH from Pseudomonas sp. ATCC17453 is much higher than the known BDH from plant (Croteau et al. 1978; Dehal and Croteau 1987; Polichuk et al. 2010; Tian et al. 2015; Fu et al. 2016; Drienovská et al. 2020) with $k_{\text {cat }}$ values for (+)borneol and (-)-borneol of 0.89 and $0.97 \mathrm{~s}^{-1}$. It lies in the same range as BDH from Pseudomonas sp. TCU-HL1 with 0.75 and $0.53 \mathrm{~s}^{-1}$ for (+)-borneol and (-)-borneol. Only recently, a novel bacterial BDH enzyme was discovered with the highest activity among all known BDH enzymes so far, with $k_{\text {cat }}$ values for (+)-borneol and (-)-borneol of 75.0 and $11.3 \mathrm{~s}^{-1}$ (Khine et al. 2020). Interestingly, this enzyme is also the first BDH enzyme, which prefers (+)-borneol as substrate. Whereas the wild-type BDH from Pseudomonas sp. ATCC17453 shows no enantioselectivity, it is the first BDH enzyme capable of catalyzing the reverse reaction from camphor to borneol. None of the other studies regarding borneol dehydrogenase has analyzed the reverse reaction (Croteau et al. 1978; Dehal and Croteau 1987; Polichuk et al. 2010; Tian et al. 2015; Fu et al. 2016; Drienovská et al. 2020; Khine et al. 2020) nor could detect any reductive activity of 


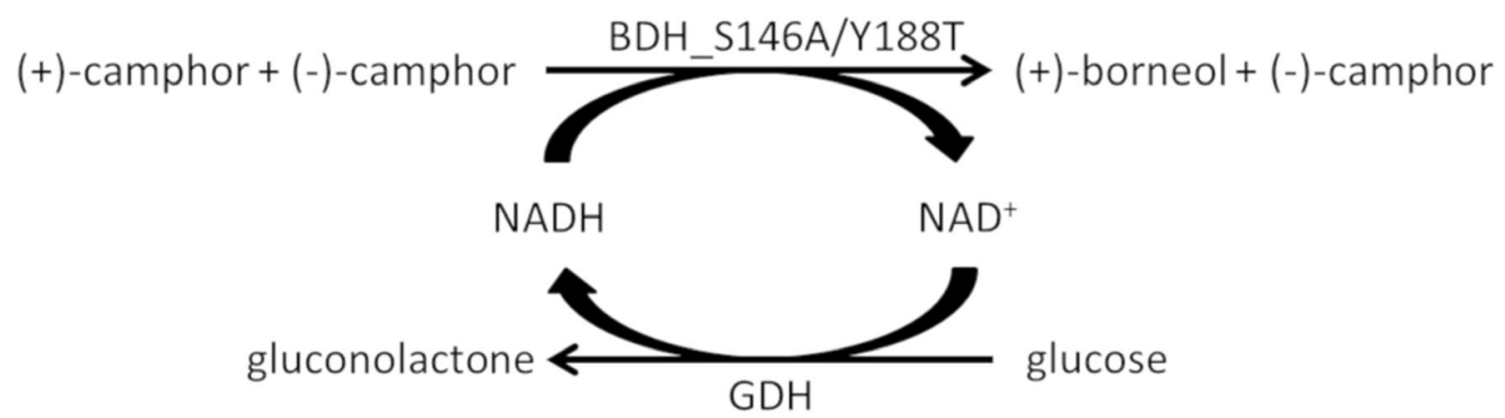

Fig. 5 Enzymatic kinetic resolution of camphor. GDH catalyzes the conversion of glucose to gluconolactone while $\mathrm{NAD}^{+}$is reduced. $\mathrm{BDH}$ catalyzes the conversion of (+)-camphor to (+)-borneol while NADH is oxidized to $\mathrm{NAD}^{+}$

the enzyme so far (Sarker et al. 2012). A tropinone reductaselike short-chain reductase was reported, able to convert pure (+)-camphor and (-)-borneol with a $k_{\text {cat }}$ of 0.06 and 0.09 , respectively (Reinhardt et al. 2014). Recently, an alcohol dehydrogenase from Salvia rosmarinus showed also low activity in the reduction of racemic camphor (Chánique et al. 2021). Due to the low activity, these enzymes are unsuitable for the desired kinetic resolution of camphor. By using BDH from Pseudomonas sp. ATCC17453, an enzymatic kinetic resolution of camphor racemate to yield pure (-)-camphor is realizable. Since the wild type shows virtually no enantioselectivity, enzyme engineering was applied to yield variants with outstanding selectivity. It has been shown that mutations close to the substrate binding site are more efficient in generating enantioselective enzyme variants (Morley and Kazlauskas 2005). By applying this strategy to the wild-type BDH, six positions close to the modeled substrate could be identified as targets for a semi-rational engineering approach (Q96, H98, E145, S146, N154, and Y188). The selected positions are not directly involved in cofactor binding or the catalytic mechanism. A common approach is to use site-directed saturation mutagenesis or CASTing (combinatorial active-site saturation test) as efficient engineering strategy to reduce the screening space (Reetz 2011). In this study, the screening space was further reduced, by a limited site-directed mutagenesis approach only generating 9-12 mutations at each site instead of 20 to reduce the screening effort. Through this approach,

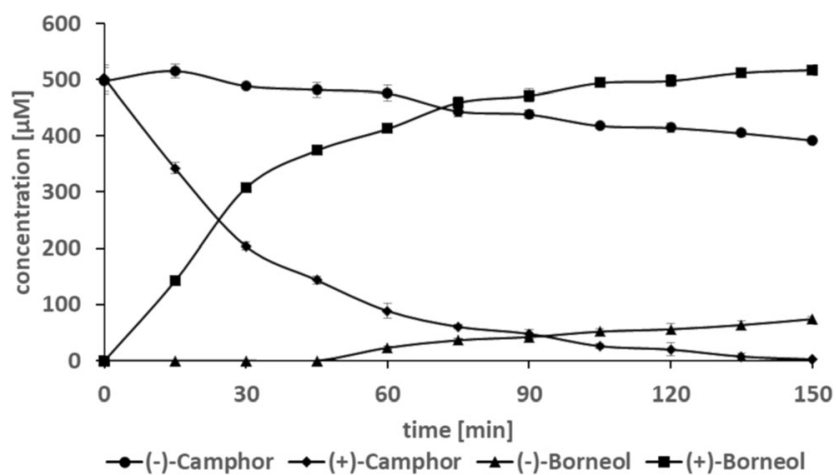

Fig. 6 Time course of the enzymatic kinetic resolution of camphor double mutants with high enantioselectivity and high activity were generated in just two mutation rounds. The best variant, BDH S146A/Y188T, has an $E$-value $>100$ for (+)-camphor and is therefore useful for the enzymatic kinetic resolution of camphor. For an efficient process, the cofactor NADH has to be recycled to drive the equilibrium to (+)-borneol (Kroutil et al. 2004). Therefore, a coupled enzyme approach with glucose dehydrogenase and glucose as second substrate was established. This approach resulted in $e e_{S}$ of $>99 \%$ with a yield of $79 \%$ of (-)-camphor. Although the enantioselectivity is quite good, the overall yield of (-)-camphor is not reaching the theoretical yield due to a low activity of the mutant enzyme with (-)-camphor. Further enzyme engineering has to be applied to realize an economical viable deracemization process.

Author contribution $\mathrm{MH}, \mathrm{RK}$, and VS conceived and designed research. JD and BB conducted experiments. RK contributed analytical tools. MH, JD, and BB analyzed data. MH wrote the manuscript. All authors read and approved the manuscript.

Funding Open Access funding enabled and organized by Projekt DEAL. This study was supported by the German Federal Ministry of Education and Research (grant no. 031B0501B).

Data availability statement All data generated or analyzed during this study are included in this published article (and its supplementary information files).

\section{Declarations}

Ethical approval This article does not contain any studies with human participants or animals performed by any of the authors.

Conflict of interest The authors declare that they have no competing interests.

Open Access This article is licensed under a Creative Commons Attribution 4.0 International License, which permits use, sharing, adaptation, distribution and reproduction in any medium or format, as long as you give appropriate credit to the original author(s) and the source, provide a link to the Creative Commons licence, and indicate if changes were made. The images or other third party material in this article are included 
in the article's Creative Commons licence, unless indicated otherwise in a credit line to the material. If material is not included in the article's Creative Commons licence and your intended use is not permitted by statutory regulation or exceeds the permitted use, you will need to obtain permission directly from the copyright holder. To view a copy of this licence, visit http://creativecommons.org/licenses/by/4.0/.

\section{References}

Banthorpe DV, Charlwood BV, Francis MJ (1972) The biosynthesis of monoterpenes. Sogo Kango 72:115-155

Bradshaw WH, Conrad HE, Corey EJ, Gunsalus IC, Lednicer D (1959) Microbial degradation of (+)-camphor. J Am Chem Soc 81:55075507

Breuer M, Ditrich K, Habicher T, Hauer B, Kesseler M, Sturmer R, Zelinski $T$ (2004) Industrial methods for the production of optically active intermediates. Angew Chem Int Ed Eng 43:788-824

Chánique AM, Dimos N, Drienovská I, Calderini E, Pantín MP, Helmer CPO, Hofer M, Sieber V, Parra LP, Loll B, Kourist R (2021) A structural view on the stereospecificity of plant borneol-type dehydrogenases. ChemCatChem. https://doi.org/10.1002/cctc. 202100110

Croteau R, Hooper CL, Felton M (1978) Biosynthesis of monoterpenes. Partial purfication and characterization of a bicyclic monoterpenol dehydrogenase from sage (Salvia officinalis). Arch Biochem Biophys 188:182-193

Dehal SS, Croteau R (1987) Metabolism of monoterpenes: specificity of the dehydrogenases responsible for the biosynthesis of camphor, 3thujone, and 3-isothujone. Arch Biochem Biophys 258:287-291

Drienovská I, Kolanović D, Chánique A, Sieber V, Hofer M, Kourist R (2020) Molecular cloning and functional characterization of a two highly stereoselective borneol dehydrogenases from Salvia officinalis L. Phytochemistry 172:112227

Edelheit O, Hanukoglu A, Hanukoglu I (2009) Simple and efficient sitedirected mutagenesis using two single-primer reactions in parallel to generate mutants for protein structure-function studies. BMC Biotechnol 9:61

Fu X, Shi P, Shen Q, Jiang W, Tang Y, Lv Z, Yan T, Li L, Wang G, Sun X, Tang K (2016) T-shaped trichome-specific expression of monoterpene synthase $\mathrm{ADH} 2$ using promoter-beta-GUS fusion in transgenic Artemisia annua L. Biotechnol Appl Biochem 63:834-840

Gasteiger E, Hoogland C, Gattiker A, Duvaud Se, Wilkins MR, Appel RD, Bairoch A (2005) Protein identification and analysis tools on the ExPASy server. In: Walker JM (ed) The Proteomics Protocols Handbook. Humana Press, Totowa, NJ, pp 571-607

Ghosh D, Wawrzak Z, Weeks CM, Duax WL, Erman M (1994) The refined three-dimensional structure of 3 alpha, 20 betahydroxysteroid dehydrogenase and possible roles of the residues conserved in short-chain dehydrogenases. Structure 2:629-640

Hartline RA, Gunsalus IC (1971) Induction specificity and catabolite repression of the early enzymes in camphor degradation by Pseudomonas putida. J Bacteriol 106:468-478

Kavanagh KL, Jornvall H, Persson B, Oppermann U (2008) Mediumand short-chain dehydrogenase/reductase gene and protein families: the SDR superfamily: functional and structural diversity within a family of metabolic and regulatory enzymes. Cell Mol Life Sci 65: 3895-3906

Khine AA, Yang M-Y, Hu A, Lin G-H, Toh Y-H, Chen H-P (2020) Production of optically pure (-)-borneol by Pseudomonas monteilii TCU-CK1 and characterization of borneol dehydrogenase involved. Enzym Microb Technol 139:109586
Klesmith JR, Bacik JP, Wrenbeck EE, Michalczyk R, Whitehead TA (2017) Trade-offs between enzyme fitness and solubility illuminated by deep mutational scanning. Proc Natl Acad Sci U S A 114:22652270

Kroutil W, Mang H, Edegger K, Faber K (2004) Recent advances in the biocatalytic reduction of ketones and oxidation of sec-alcohols. Curr Opin Chem Biol 8:120-126

Morley KL, Kazlauskas RJ (2005) Improving enzyme properties: when are closer mutations better? Trends Biotechnol 23:231-237

Morris GM, Huey R, Lindstrom W, Sanner MF, Belew RK, Goodsell DS, Olson AJ (2009) AutoDock4 and AutoDockTools4: automated docking with selective receptor flexibility. J Comput Chem 30: 2785-2791

Polichuk DR, Zhang Y, Reed DW, Schmidt JF, Covello PS (2010) A glandular trichome-specific monoterpene alcohol dehydrogenase from Artemisia annua. Phytochemistry 71:1264-1269

Reetz MT (2011) Laboratory evolution of stereoselective enzymes: a prolific source of catalysts for asymmetric reactions. Angew Chem Int Ed Eng 50:138-174

Reinhardt N, Fischer J, Coppi R, Blum E, Brandt W, Drager B (2014) Substrate flexibility and reaction specificity of tropinone reductaselike short-chain dehydrogenases. Bioorg Chem 53:37-49

Sarker LS, Galata M, Demissie ZA, Mahmoud SS (2012) Molecular cloning and functional characterization of borneol dehydrogenase from the glandular trichomes of Lavandula $x$ intermedia. Arch Biochem Biophys 528:163-170

Selescu T, Ciobanu AC, Dobre C, Reid G, Babes A (2013) Camphor activates and sensitizes transient receptor potential melastatin 8 (TRPM8) to cooling and icilin. Chem Senses 38:563-575

Sherkheli MA, Vogt-Eisele AK, Weber K, Hatt H (2013) Camphor modulates TRPV 3 cation channels activity by interacting with critical pore-region cysteine residues. Pak J Pharm Sci 26:431-438

Smialowski P, Martin-Galiano AJ, Mikolajka A, Girschick T, Holak TA, Frishman D (2007) Protein solubility: sequence based prediction and experimental verification. Bioinformatics 23:2536-2542

Tian Y, Deutsch C, Krishnamoorthy B (2010) Scoring function to predict solubility mutagenesis. Algorithm Mol Biol 5:33

Tian N, Tang Y, Xiong S, Tian D, Chen Y, Wu D, Liu Z, Liu S (2015) Molecular cloning and functional identification of a novel borneol dehydrogenase from Artemisia annua L. Ind Crop Prod 77:190-195

Trott O, Olson AJ (2010) AutoDock Vina: improving the speed and accuracy of docking with a new scoring function, efficient optimization, and multithreading. J Comput Chem 31:455-461

Tsang HL, Huang JL, Lin YH, Huang KF, Lu PL, Lin GH, Khine AA, $\mathrm{Hu}$ A, Chen HP (2016) Borneol dehydrogenase from Pseudomonas $s p$. Strain TCU-HL1 catalyzes the oxidation of (+)-borneol and its isomers to camphor. Appl Environ Microbiol 82:6378-6385

Verho O, Backvall JE (2015) Chemoenzymatic dynamic kinetic resolution: a powerful tool for the preparation of enantiomerically pure alcohols and amines. J Am Chem Soc 137:3996-4009

Waterhouse A, Rempfer C, Heer FT, Studer G, Tauriello G, Bordoli L, Bertoni M, Gumienny R, Lepore R, Bienert S, de Beer TAP, Schwede T (2018) SWISS-MODEL: homology modelling of protein structures and complexes. Nucleic Acids Res 46:W296-W303

$\mathrm{Xu} \mathrm{H}$, Blair NT, Clapham DE (2005) Camphor activates and strongly desensitizes the transient receptor potential vanilloid subtype 1 channel in a vanilloid-independent mechanism. J Neurosci 25:8924 8937

Zhen-dong Z, Liang-wu B (2009) Industrial status and development of synthetic camphor. Biomass Chem Eng 43:1-8

Publisher's note Springer Nature remains neutral with regard to jurisdictional claims in published maps and institutional affiliations. 